\title{
Microbiological and faunal soil attributes of coffee cultivation under different management systems in Brazil
}

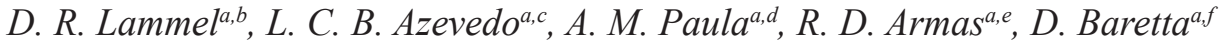 \\ and E. J. B. N. Cardoso ${ }^{a *}$ \\ aDepartamento de Ciência do Solo, Escola Superior de Agricultura “Luiz de Queiroz" - ESALQ, \\ Universidade de São Paulo - USP, Av. Pádua Dias, 11, CEP 13418-900, Piracicaba, SP, Brazil

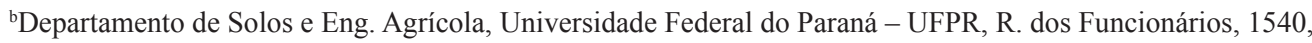 \\ CEP 80035-050, Curitiba, PR, Brasil \\ 'Instituto de Ciências Agrárias, Universidade Federal de Uberlândia - UFU, Av. Amazonas, s/n, Bloco 2E, \\ CEP 38400-902, Uberlândia, MG, Brazil \\ ${ }^{\mathrm{d}}$ Departamento de Microbiologia, Imunologia e Parasitologia, Universidade Federal de Santa Catarina - UFSC, \\ Campus Universitário Reitor João David Ferreira Lima, Bairro Trindade, CEP 88040-900, Florianópolis, SC, Brazil

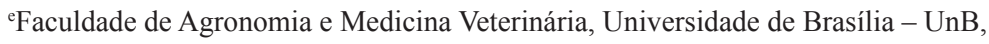 \\ Campus Universitário Darcy Ribeiro, CEP 70910-900, Brasília, DF, Brasil \\ fDepartamento de Ciência Animal, Centro de Educação Superior do Oeste - CEO, Universidade do Estado de Santa \\ Catarina - UDESC, Rua Beloni Trombeta Zanin, 680E, CEP 89815-630, Chapecó, SC, Brazil \\ *e-mail: ejbncard@usp.br
}

Received: February 19, 2014 - Accepted: April 8, 2014 - Distributed: November 30, 2015

(With 2 figures)

\begin{abstract}
Brazil is the biggest coffee producer in the world and different plantation management systems have been applied to improve sustainability and soil quality. Little is known about the environmental effects of these different management systems, therefore, the goal of this study was to use soil biological parameters as indicators of changes. Soils from plantations in Southeastern Brazil with conventional (CC), organic (OC) and integrated management systems containing intercropping of Brachiaria decumbens (IB) or Arachis pintoi (IA) were sampled. Total organic carbon (TOC), microbial biomass carbon $(\mathrm{MBC})$ and nitrogen $(\mathrm{MBN})$, microbial activity $\left(\mathrm{C}-\mathrm{CO}_{2}\right)$, metabolic quotient $\left(q \mathrm{CO}_{2}\right)$, the enzymes dehydrogenase, urease, acid phosphatase and arylsulphatase, arbuscular mycorrhizal fungi (AMF) colonization and number of spores and soil fauna were evaluated. The greatest difference between the management systems was seen in soil organic matter content. The largest quantity of TOC was found in the OC, and the smallest was found in IA. TOC content influenced soil biological parameters. The use of all combined attributes was necessary to distinguish the four systems. Each management presented distinct faunal structure, and the data obtained with the trap method was more reliable than the TSBF (Tropical Soils) method. A canonic correlation analysis showed that Isopoda was correlated with TOC and the most abundant order with OC. Isoptera was the most abundant faunal order in IA and correlated with MBC. Overall, OC had higher values for most of the biological measurements and higher populations of Oligochaeta and Isopoda, corroborating with the concept that the OC is a more sustainable system.
\end{abstract}

Keywords: Coffea arabica L., soil macrofauna, soil metabolism.

\section{Atributos microbiológicos e da fauna do solo com diferentes sistemas de cultivo de cafeeiro no Brasil}

\section{Resumo}

O Brasil é o maior produtor mundial de café e diferentes sistemas de manejo têm sido aplicados para melhorar a sustentabilidade e a qualidade do solo. Pouco se conhece sobre os efeitos ambientais desses sistemas de manejo, assim, o objetivo desse estudo foi utilizar parâmetros biológicos do solo como indicadores de mudanças nos sistemas. Foram amostrados, na região sudeste do Brasil, solos com cultivo convencional (CC), orgânico (OC) e sistema integrado de cultivo consorciado com Brachiaria decumbens (IB) ou com Arachis pintoi (IA) na entrelinha. Foram avaliados o carbono orgânico total (TOC), carbono e nitrogênio da biomassa microbiana (MBC e MBN), atividade microbiana $\left(\mathrm{C}-\mathrm{CO}_{2}\right)$, quociente metabólico $\left(q \mathrm{CO}_{2}\right)$, as enzimas desidrogenase, urease, fosfatase ácida e arilsulfatase, a colonização e número de esporos de fungos micorrízicos arbusculares (AMF) e a fauna do solo. A maior diferença entre os sistemas de manejo foram verificadas no teor de matéria orgânica do solo. O maior teor de TOC foi encontrado no OC, e o 
menor teor encontrado no sistema IA. O teor de TOC influenciou os parâmetros biológicos e a diferenciação da fauna do solo. O uso combinado de todos os atributos foi necessário para diferenciar os quatro sistemas de cultivo. Cada manejo apresentou estruturas diferentes de fauna, e dados obtidos com o método de armadilhas tipo pitfall foi mais confiável do que o método TSBF (Solos Tropicais). A análise de correlação canônica mostrou que Isopoda foi correlacionado com TOC e a ordem mais abundante em OC. Isoptera foi a ordem da fauna mais abundante em IA e foi correlacionada com MBC. Em geral, OC apresentou os maiores valores para a maioria dos atributos biológicos, inclusive para abundância de indivíduos de Oligochaeta e Isopoda, corroborando com o conceito de que OC é um sistema mais sustentável.

Palavras-chave: Coffea arabica L., macrofauna do solo, metabolismo do solo.

\section{Introduction}

Coffee is one of the most important tropical crops in the world, with an estimated exports trade of US\$ 15.4 billion in $2012 / 2013$, according to the International Coffee Organization (ICO, 2014). The world total production of coffee beans was more than 145 million bags ( 8.7 teragrams) in 2013 (ICO, 2014). With 2.2 million hectares of cultivated area, Brazil is the largest producer in the world (Brasil, 2014). In the year 2013/2014, Brazil had an estimated production of 53.7 million bags (3.2 teragrams) of coffee, which corresponds to approximately one third of the world production (Brasil, 2014).

During the last decades, many farmers adopted alternative management systems such as coffee being produced under organic farming. The main driver for this change was the higher prices paid for products of organic origin, even without considering the technical and environmental aspects. Information about best management practices for sustainable crop production is scarce, and the priority should focus on which management systems can sustain or improve the physical, chemical and biological attributes of the soil (Bhardwaj et al., 2011; Lima et al., 2013; Doran and Zeiss, 2000). Evaluating soil quality in the field, where contrasting production methods are used, will help with the understanding of how sustainable these practices are, and the development of soil management strategies (Bhardwaj et al., 2011; Garrigues et al., 2012).

Current understanding of soil biological processes is not comprehensive enough to use them solely as soil quality (SQ) indicators, even though a great effort is being made in this respect. However, the importance of the biological soil attributes for the soil sustainability is consensual (Chaer et al., 2009; Rutgers et al., 2012). Influencing several biological attributes, the soil organic matter (SOM) is as a key indicator of SQ. Besides fulfilling the basic requirement of being sensitive to soil management changes, the SOM influences water infiltration and retention, soil susceptibility to erosion, and, additionally, its mineralization is an important source of nutrients for plants (Blanco-Canqui et al., 2013; Chaer et al., 2009; Velasquez et al., 2007).

Several biological attributes have potential to be used as SQ. The microbial activity may be used to understand the soil mineralization processes, the intensity of the energy flow in the soil, and to monitor SOM decomposition (Anderson, 2003; Schmidt et al., 2011). The microbial biomass is related to the processes of organic matter decomposition, interacting with nutrient dynamics, and the regeneration of soil aggregate stability (Cotrufo et al., 2013; Velasquez et al., 2007).

Other potential indicators are the soil macrofauna and microbiota, which respond rapidly to environmental changes, due to their quick adaptation to new conditions, being able to detect alterations prior to any change of physical and chemical patterns of the soil (Baretta et al., 2007a). Among them, arbuscular mycorrhizal fungi, soil enzymatic activity and the composition and abundance of the soil fauna may indicate changes imposed to the soil environment by management techniques (Andrade et al., 2009; Balota and Chaves, 2010; Chaer et al., 2009; Velasquez et al., 2007).

Nowadays, the use of soil fauna as bio-indicator of soil quality is becoming more common, since they have several crucial functions in soil systems, e.g. soil structure (Brussaard et al., 2007). The faunal groups can be useful for comparing crops and the intensity of human intervention in agroecosystems, considering the fact that their interactions with abiotic factors affect their functions (Coleman, 2008; Karanja et al., 2009; Socarrás, 2013). Thus, a study of faunal groups together with biochemical and other biological features of soil and their correlations can be used as robust indicators of soil quality (Velasquez et al., 2007).

The objective of this study was to evaluate the influence of different coffee management systems on biological parameters. And the hypothesis that TOC, biological attributes and faunal groups in the soil will serve as indicators of soil quality in different coffee management systems was tested.

\section{Material and Methods}

\subsection{Sampling sites description}

Soil samples from different coffee management systems were collected from two farms in April, 2006, in the southern part of Minas Gerais State. This region is the largest C. arabica producing state in Brazil $(69 \%$ of the production) (Brasil, 2014). Typical farms that represent popular practices in the region were chosen.

On the first farm (coordinates $21^{\circ} 42^{\prime} 30^{\prime \prime} \mathrm{S}$ e $46^{\circ} 34^{\prime} 20^{\prime \prime} \mathrm{W}$ ), conventional and organic coffee fields were sampled. The conventional coffee field was planted in rows spaced $2.0 \mathrm{~m} \times 1.0 \mathrm{~m}$ apart and the coffee cultivar used was Acaiá 417/19 planted in 1976. In 2001, 22.5 ha of this conventional coffee area were converted into organic management. The differences between both fields were that 
in the organically managed field organic amendments were added to the soil and no pesticides or chemical fertilizers used. Organic materials added included coffee grain husk (5.0 $\mathrm{Mg} \mathrm{ha}^{-1}$ year-1 $^{-1}$ ) and castor bean cake (Ricinus communis L.) (6.5 $\mathrm{Mg} \mathrm{ha}^{-1}$ year $\left.^{-1}\right)$. In the conventional area an average of $400 \mathrm{~kg} \mathrm{ha}^{-1}$ year $^{-1}$ of $\mathrm{N}$ and $\mathrm{K}$ and $100 \mathrm{~kg} \mathrm{ha}^{-1}$ year $^{-1}$ of P were applied as synthetic fertilizers, and coffee grain husk was sporadically applied in very small amounts. In the conventional system, the coffee rust fungus Hemileia vastatrix Berk \& Br. was controlled by using thiamethoxam $(30 \% \mathrm{~m} / \mathrm{m})$ and cyproconazole $(30 \%$ $\mathrm{m} / \mathrm{m}$ ), and Hypothenemus hampei Ferrari (the coffee berry borer) was controlled with endosulfan. Soil chemical parameters were analyzed according to van Raij et al. (2001). In the organic fields, the chemical measurements were: $\mathrm{pH}\left(\mathrm{CaCl}_{2}\right), 5.9 ; \mathrm{P}, 93\left(\mathrm{mg} \mathrm{dm}^{-3}\right) ; \mathrm{K}^{+}, 8.3, \mathrm{Ca}^{+2}$, $72, \mathrm{Mg}^{+2}, 27\left(\mathrm{mmol} \mathrm{dm}^{-3}\right)$. The chemical measurements in the conventional fields were: $\mathrm{pH}\left(\mathrm{CaCl}_{2}\right), 4.9 ; \mathrm{P}$, $38\left(\mathrm{mg} \mathrm{dm}{ }^{-3}\right) ; \mathrm{K}^{+}, 5.4, \mathrm{Ca}^{+2}, 39, \mathrm{Mg}^{+2}, 12\left(\mathrm{mmol}_{\mathrm{c}} \mathrm{dm}^{-3}\right)$.

In the second farm (coordinates $22^{\circ} 17^{\prime} 02^{\circ}$ ' $\mathrm{S}$ and $46^{\circ} 22^{\prime} 02^{\prime \prime} \mathrm{W}$ ), soil samples from integrated coffee plantation management systems were collected, with two different green manure crops between the coffee rows: Arachis pintoi Krapov \& WC Greg. (Fabaceae/Leguminoseae) and Brachiaria decumbens Stapf (Poaceae/Gramineae). In both integrated fields $150 \mathrm{~kg} \mathrm{ha}^{-1}$ year $^{-1}$ of N and $124 \mathrm{~kg} \mathrm{ha}^{-1}$ year $^{-1}$ of $\mathrm{K}$ were applied. In the integrated system, pesticides are only used based on need, and this is in contrast to conventional system in which regular applications of the pesticides are made. In the integrated management system, thiamethoxam $(30 \% \mathrm{~m} / \mathrm{m})$, cyproconazole $(30 \% \mathrm{~m} / \mathrm{m})$ and azoxystrobin $(50 \% \mathrm{~m} / \mathrm{m})$ were sometimes used to control the plant pathogens (Hemileia vastatrix Berk \& Br. and Cercospora zeae-maydis Tehon \& Daniels). Besides, the intercalary plants are pruned periodically, and their clippings remain on the soil in the cultivation area, which allows the accumulation of organic matter, improving nutrient cycling. The coffee cultivar grown in this area is Catuaí IAC 99, planted in 2002, spaced $2.0 \mathrm{~m} \times 1.0 \mathrm{~m}$ apart. The chemical parameters analyzed according to van Raij et al. (2001) for these areas were: $\mathrm{pH}\left(\mathrm{CaCl}_{2}\right) 4.3 ; \mathrm{P}, 19\left(\mathrm{mg} \mathrm{dm}^{-3}\right) ; \mathrm{K}^{+}, 3.6$, $\mathrm{Ca}^{+2}, 20, \mathrm{Mg}^{+2}, 4\left(\mathrm{mmol}_{\mathrm{c}} \mathrm{dm}^{-3}\right)$, for the $A$. pinto $i$ area, and, $\mathrm{pH}\left(\mathrm{CaCl}_{2}\right)$, 4.6; $\mathrm{P}, 20\left(\mathrm{mg} \mathrm{dm}^{-3}\right) ; \mathrm{K}^{+}, 3.5, \mathrm{Ca}^{+2}, 34, \mathrm{Mg}^{+2}$, $12\left(\mathrm{mmol}_{\mathrm{c}} \mathrm{dm}^{-3}\right)$ for the area with $B$. decumbens.

From now on the following abbreviations will be used for the different management systems: OC for coffee under organic management, $\mathrm{CC}$ for coffee under conventional management, IA for coffee with integrated management and Arachis pintoi between rows and IB for coffee with integrated management and Brachiaria decumbens between rows.

\subsection{Soil sampling}

To optimize the soil sampling, three replicate random rows of coffee trees were chosen in each field. In the first two rows three sampling points $20 \mathrm{~m}$ apart were chosen and in the third longer row four sampling points were chosen. A total of ten soil samples per management system were collected, from three replicate rows, considering a random design.

Each sample was composed by five sub-samples, collected at a depth of $20 \mathrm{~cm}$, below the crowns of the coffee trees, at the aforementioned points. The sampling method was standardized for all soil analyzes, to allow the comparison of all variables in the multivariate analysis. Soil samples were kept at $4{ }^{\circ} \mathrm{C}$ until the analysis, within approximately a month.

\subsection{TOC, $\mathrm{C}-\mathrm{CO}_{2}, \mathrm{MBC}$ and $\mathrm{MBN}$}

To determine the TOC a variation of the Walkey-Black method was used, according to van Raij et al. (2001). From the 10 samples collected in each area, five random replications were used. The $\mathrm{C}-\mathrm{CO}_{2}$ and $\mathrm{q} \mathrm{CO}_{2}$ of the areas was determined by the Anderson and Domsch (1989) methodology, with a soil incubation period of seven days, while the MBC and the MBN were evaluated through the fumigation-extraction method (Vance et al., 1987).

\subsection{Enzymatic activity}

The acid phosphatase analysis was performed according to the methodology of Tabatabai and Bremner (1969), with the following modification: the extract was diluted 10 times and the absorbency was read at $400 \mathrm{~nm}$. Arylsulphatase activity was determined according to the methodology of Tabatabai and Bremner (1970), dehydrogenase activity according to Casida-Júnior et al. (1964) and urease activity was estimated according to Tabatabai and Bremner (1972). Six replicates were analyzed, randomly selected from the 10 samples collected in each coffee management area.

\subsection{Root colonization and AMF spore density}

Roots of coffee plants were manually collected at $5 \mathrm{~cm}$ depth in the soil below the tree canopies. The sampled roots were rinsed in running water and treated with $\mathrm{KOH}$ $10 \%$ for 60 minutes at $90{ }^{\circ} \mathrm{C}$. Afterwards, the roots were bleached with $15 \% \mathrm{H}_{2} \mathrm{O}_{2}$ for 10 seconds. The fungal structures inside the roots were dyed for 3 min with 5\% pen ink, diluted in a $5 \%$ acetic acid solution at $90{ }^{\circ} \mathrm{C}$ (Vierheilig et al., 1998). For each sample, twenty segments of $1 \mathrm{~cm}$ of the dyed roots were mounted on a microscope slides and were evaluated under a microscope.

The spores were extracted of $50 \mathrm{~g}$ of soil through wet sieving, according to Gerdemann and Nicolson (1963) and centrifuged in water at $3000 \mathrm{rpm}$ for 3 minutes and in $70 \%$ sucrose at $2000 \mathrm{rpm}$ for 2 minutes. The extracted spores were rinsed in running water on a $38 \mu \mathrm{m}$ mesh sieve. The spores were counted on a plate with concentric grooves under a stereo microscope. All 10 samples collected in each area were used for the analysis.

\subsection{Soil fauna}

The soil fauna was analyzed by means of two different methods: pit-fall traps and soil monoliths; soil monoliths are recommended by the "Tropical Soil Biology and Fertility" (TSBF) Program (Baretta et al., 2007a).

The setting of the traps aimed at collecting organisms from the meso and macrofauna with epigean ecologic 
behavior (Baretta et al., 2007a). Each trap was filled with $200 \mathrm{~mL}$ of a solution composed of $15 \mathrm{~mL}$ of detergent per 1 liter of water, and the traps were introduced into the soil at the 10 previously established points for each area.

For the soil monoliths, five locations were randomly selected, and a monolith measuring $25 \mathrm{~cm}$ square and $30 \mathrm{~cm}$ deep was collected in each area, close to each coffee tree selected for general soil sampling. The soil organisms were manually separated and identified at the level of taxonomic orders, with the aid of a stereo microscope with $100 \mathrm{X}$ magnification.

Shannon's diversity index, Simpson's dominance index, Pielou's evenness index, groups richness, richness estimate by the ACE method modified for more heterogeneous communities and the estimated sample coverage were calculated with the SPADE program (Chao and Shen, 2003).

\subsection{Statistical analysis}

Data obtained from the different analysis methods were submitted to analysis of variances (ANOVA) and the means of the microbial variables by the Duncan's post-hoc test and the density of the macrofauna by the LSD post-hoc test.

Canonical correlation analysis (CCA) was used to associate the different attributes and management systems. The biochemical and microbiological soil attributes were used in the CCA as environmental variables to be correlated with the density of the soil fauna groups for each management system. Analyses were performed using the software CANOCO (Leps and Smilauer, 2003).

\section{Results}

\subsection{TOC, $\mathrm{C}-\mathrm{CO}_{2}, q C \mathrm{CO}_{2}, \mathrm{MBC}$ and $\mathrm{MBN}$}

The OC system had the highest TOC, followed by IB, $\mathrm{CC}$, and finally the IA $(p<0.05)$. With respect to $\mathrm{C}-\mathrm{CO}_{2}$, the greatest values were found in the IB, $\mathrm{CC}$ and $\mathrm{OC}$, while the smallest value was found in the IA. The IA had the highest MBC as well as OC which did not differ from IB and CC. The CC presented a higher MBN, followed by IA, OC and IB. CC had the lowest MBC/MBN ratio while IA had a MBC/TOC ratio superior to the others. IA had the lowest $q \mathrm{CO}_{2}$ of all management systems (Table 1).

According to the CCA, TOC was the most efficient attribute to discriminate the four management systems. The other indicators $\left(\mathrm{MBC}, \mathrm{MBN}\right.$ and $\mathrm{C}-\mathrm{CO}_{2}$ ) were able to discriminate one or the other system, and only when all parameters were used together it was possible to discriminate all four systems (Figure 1).

\subsection{Enzymatic activity}

The IA area presented the lowest values and differed from $\mathrm{OC}$ for all enzymes evaluated (Table 1). Phosphatase and urease activity were greater in OC than in $\mathrm{CC}(p<0.05)$. $\mathrm{CC}$ and IB differed only in the phosphatase activity. In general, $\mathrm{OC}$ presented a higher enzymatic activity while CC, IB and IA showed lower values, which was similar to the pattern observed for TOC (Figure 2).

\subsection{Mycorrhizal colonization and AMF spore density in the soil}

In all samples the roots were colonized by AMF with the presence of hyphae, arbuscules and vesicles. The greatest colonization percentage was observed in IB areas (Table 1). No significant difference was found in the number of spores under different management systems using univariate analysis, though the CCA had greater number of spores associated with OC (Figure 1).

\subsection{Soil fauna}

Structural differences in the faunal communities $(p<0.1)$ were verified with the use of both sampling methods, monoliths and traps (Tables 2 and 3).

Table 1. Soil attributes of coffee plantations under conventional (CC), organic (OC) and integrated management systems intercropped with $A$. pintoi (IA) or B. decumbens (IB).

\begin{tabular}{|c|c|c|c|c|c|c|c|c|c|c|}
\hline Analysis & Unit & \multicolumn{2}{|c|}{$\mathbf{C C}$} & \multicolumn{2}{|c|}{ OC } & \multicolumn{2}{|c|}{ IA } & \multicolumn{2}{|c|}{ IB } & CV $(\%)^{\mathrm{a}}$ \\
\hline TOC & $\mathrm{g} \mathrm{kg}^{-1}$ dry soil & 14.5 & $c^{b}$ & 20.6 & a & 12.8 & d & 16.9 & $\mathrm{~b}$ & 5.3 \\
\hline $\mathrm{MBC}$ & $\mu \mathrm{g} \mathrm{g}^{-1}$ dry soil & 287.4 & $\mathrm{~b}$ & 350.0 & $a b$ & 449.6 & $\mathrm{a}$ & 273.4 & $\mathrm{~b}$ & 4.3 \\
\hline $\mathrm{MBN}$ & $\mu \mathrm{g} \mathrm{g}^{-1}$ dry soil & 52.6 & $\mathrm{a}$ & 29.3 & $\mathrm{~b}$ & 30.3 & $\mathrm{~b}$ & 18.6 & $\mathrm{c}$ & 15.6 \\
\hline $\mathrm{MBC} / \mathrm{MBN}$ & - & 5.6 & b & 12.1 & $\mathrm{a}$ & 15.1 & $\mathrm{a}$ & 16.4 & $\mathrm{a}$ & 14.2 \\
\hline $\mathrm{MBC} / \mathrm{TOC}$ & - & 11.5 & b & 9.9 & $\mathrm{~b}$ & 20.5 & $\mathrm{a}$ & 9.4 & $\mathrm{~b}$ & 9.9 \\
\hline $\mathrm{C}-\mathrm{CO}_{2}$ & $\begin{array}{c}\text { mg C-CO } \mathrm{CO}_{2} \mathrm{~kg}^{-1} \text { dry } \\
\text { soil h } \mathrm{h}^{-1}\end{array}$ & 8.7 & $\mathrm{a}$ & 7.4 & $\mathrm{ab}$ & 6.7 & $\mathrm{~b}$ & 8.8 & $\mathrm{a}$ & 26.2 \\
\hline$q \mathrm{CO}_{2}$ & $\mathrm{mg} \mathrm{C}-\mathrm{CO}_{2} \mathrm{~g} \mathrm{MBC}^{-1} \mathrm{~h}^{-1}$ & 30.4 & $\mathrm{a}$ & 21.3 & $\mathrm{a}$ & 15.0 & b & 32.1 & a & 19.6 \\
\hline Dehydrogenase & $\mu \mathrm{g} \mathrm{TTC} \mathrm{g}^{-1} \mathrm{~h}^{-1}$ & 12.2 & $\mathrm{a}$ & 10.4 & $\mathrm{a}$ & 6.7 & a & 9.7 & $\mathrm{a}$ & 32.8 \\
\hline Urease & $\mu \mathrm{g} \mathrm{N}-\mathrm{NH}_{4}^{+} \mathrm{g}^{-1} \mathrm{~h}^{-1}$ & 3.7 & b & 5.7 & a & 2.7 & $\mathrm{~b}$ & 3.2 & $\mathrm{~b}$ & 15.5 \\
\hline Phosphatase & $m g \mathrm{PNP}^{-1} \mathrm{~h}^{-1}$ & 6.0 & $\mathrm{~b}$ & 8.3 & $\mathrm{a}$ & 4.6 & $\mathrm{~b}$ & 7.8 & a & 22.0 \\
\hline Arylsulphatase & $\mu \mathrm{g} \operatorname{PNP~g}^{-1} \mathrm{~h}^{-1}$ & 4.1 & $a b$ & 4.9 & $\mathrm{a}$ & 3.9 & $\mathrm{~b}$ & 4.4 & $\mathrm{ab}$ & 11.9 \\
\hline Colonization & $\%$ & 19.7 & $\mathrm{~b}$ & 18.8 & $\mathrm{~b}$ & 23.0 & $\mathrm{ab}$ & 31.4 & $\mathrm{a}$ & 23.1 \\
\hline Spores & spores $100 \mathrm{~g}^{-1}$ soil & 239.0 & $\mathrm{a}$ & 274.4 & $\mathrm{a}$ & 209.6 & $\mathrm{a}$ & 205.7 & $\mathrm{a}$ & 20.8 \\
\hline
\end{tabular}

${ }^{\mathrm{a}} \mathrm{CV}=$ Coefficient of Variation (ANOVA). ${ }^{\mathrm{b}}$ Data followed by the same small letter in the line do not differ by the Duncan test $(p<0.05)$. 


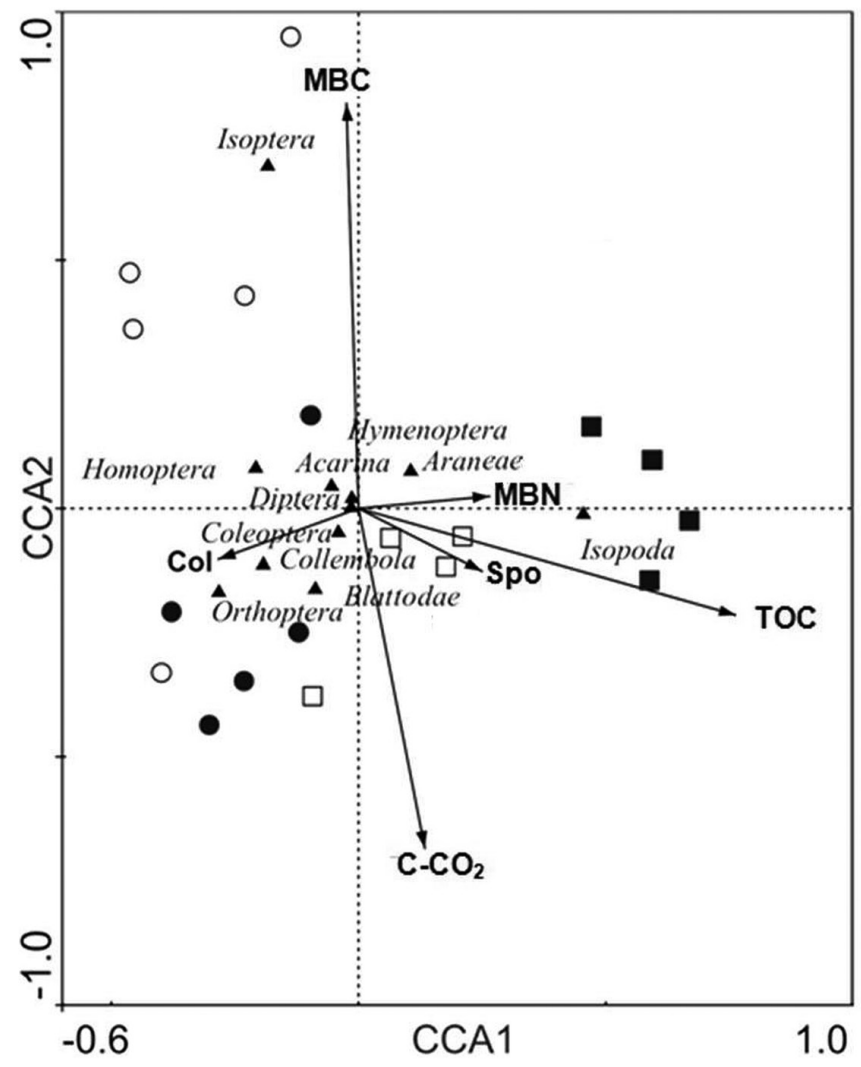

Response variable:

॥ fauna orders (traps)

Management systems:

$\square$ Conventional Coffee (CC)

- Organic Coffee (OC)

- Integrated with Brachiaria (IB)

- Integrated with Arachis (IA)

Figure 1. Canonical correlation analysis (CCA) associating biological and biochemical attributes to the management system used. Response variable: fauna groups (traps). Management systems: Conventional Coffee (CC); Organic Coffee (OC); Integrated with Brachiaria (IB); Integrated with Arachis (IA). Vectors indicate attributes used as explanatory variables: TOC, MBC, MBN, C-CO, , Col (arbuscular mycorrhizal colonization) and Spo (AMF spore density). Diptera is larvae.

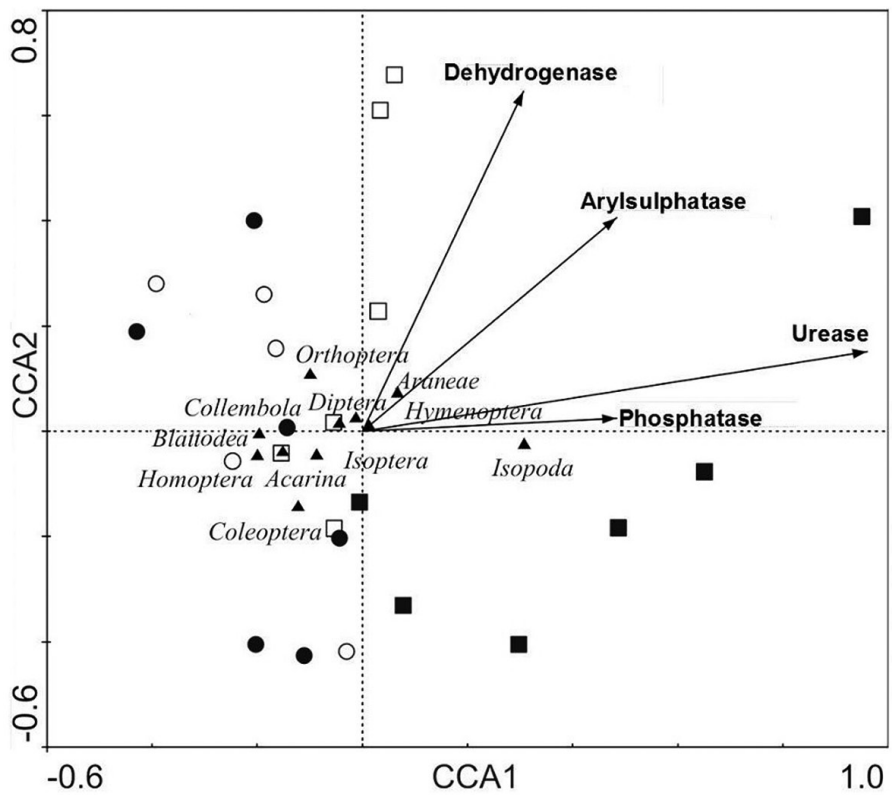

Response variable:

$\boldsymbol{\Delta}$ fauna orders (traps)

Management systems:

$\square$ Conventional Coffee (CC)

- Organic Coffee (OC)

- Integrated with Brachiaria (IB)

o Integrated with Arachis (IA)

Figure 2. Canonical correlation analysis (CCA) associating biological and biochemical attributes to the management system used. Response variable: fauna orders (traps). Management systems: Conventional Coffee (CC); Organic Coffee (OC); Integrated with Brachiaria (IB); Integrated with Arachis (IA). Vectors indicate enzymes used as explanatory variables. 
As for the soil monoliths, the great number of Mollusca and Hymenoptera in IB was obtained in only one of five replications. The same occurred with the Isoptera in IA and with Hymenoptera in CC. The best reproducibility of the data for the different repetitions occurred with Coleoptera and Oligochaeta, where the former was notably less numerous in $\mathrm{OC}$ while the latter was clearly more numerous in OC (Table 2).

The traps presented highly reproducible data for the different replications, and displayed a greater fauna richness and diversity compared with the monolith method (Table 4). Using the trap method, there was a greater occurrence of Acarina in IB and Araneae in CC, and a smaller presence

Table 2. Soil macrofauna obtained from soil monoliths sampled under coffee trees under conventional (CC), organic (OC) and integrated management systems intercropped with $A$. pintoi (IA) or $B$. decumbens (IB), compared with values reported from different coffee plantations by other authors (Velasquez et al., 2007) compared coffee intercropped with Schizolobium amazonicum and Hevea brasiliensis; Barros et al. (2002) single cropping).

\begin{tabular}{|c|c|c|c|c|c|c|c|c|c|c|c|c|}
\hline \multirow{3}{*}{ Group } & \multicolumn{8}{|c|}{ This work } & \multicolumn{3}{|c|}{ Velasquez et al. (2007) } & \multirow{3}{*}{$\begin{array}{c}\text { Barros et al. } \\
(2002)\end{array}$} \\
\hline & \multicolumn{2}{|c|}{$\mathbf{C C}$} & \multicolumn{2}{|c|}{$\mathrm{OC}$} & \multicolumn{2}{|c|}{ IA } & \multicolumn{2}{|c|}{ IB } & $\mathbf{C V}$ & S. amazonicum ${ }^{\mathrm{a}}$ & H. brasiliensis ${ }^{\mathrm{a}}$ & \\
\hline & \multicolumn{8}{|c|}{ (individuals per $\mathbf{m}^{2}$ ) } & $(\%)$ & \multicolumn{2}{|c|}{ (individuals per $\mathbf{m}^{2}$ ) } & \\
\hline Araneae & 3 & $a^{b}$ & 13 & a & 10 & $\mathrm{a}$ & 6 & $\mathrm{a}$ & 173 & 10 & 45 & 29 \\
\hline Blattodea & 0 & $\mathrm{a}$ & 0 & $\mathrm{a}$ & 3 & $\mathrm{a}$ & 3 & $\mathrm{a}$ & 316 & - & - & - \\
\hline Chilopoda & 0 & $\mathrm{a}$ & 9 & $\mathrm{a}$ & 3 & $\mathrm{a}$ & 13 & $\mathrm{a}$ & 240 & 9 & 38 & 13 \\
\hline Coleoptera & 26 & $a b$ & 0 & $\mathrm{~b}$ & 22 & $a b$ & 32 & $\mathrm{a}$ & 117 & 56 & 61 & 90 \\
\hline $\begin{array}{l}\text { Diptera } \\
\text { (larvae) }\end{array}$ & 0 & $\mathrm{a}$ & 0 & $\mathrm{a}$ & 3 & $\mathrm{a}$ & 0 & $\mathrm{a}$ & 447 & 13 & - & - \\
\hline Diplopoda & - & & - & & - & & - & & - & 4 & 86 & 58 \\
\hline Homoptera & - & & - & & - & & - & & - & 1 & 99 & 32 \\
\hline Hymenoptera & 61 & $\mathrm{a}$ & 3 & $\mathrm{a}$ & 16 & $\mathrm{a}$ & 268 & $\mathrm{a}$ & 329 & 563 & 1322 & 237 \\
\hline Heteroptera & 10 & $\mathrm{a}$ & 3 & $\mathrm{a}$ & 3 & $\mathrm{a}$ & 3 & $\mathrm{a}$ & 197 & 4 & - & - \\
\hline Isoptera & 0 & $\mathrm{a}$ & 0 & $\mathrm{a}$ & 16 & $\mathrm{a}$ & 0 & $\mathrm{a}$ & 447 & 4 & 262 & 1491 \\
\hline $\begin{array}{l}\text { Lepidoptera } \\
\text { (larvae) }\end{array}$ & 3 & $a b$ & 0 & $\mathrm{~b}$ & 10 & $\mathrm{a}$ & 0 & $\mathrm{~b}$ & 250 & 1 & - & - \\
\hline Mollusca & 10 & $\mathrm{a}$ & 42 & $\mathrm{a}$ & 22 & $\mathrm{a}$ & 38 & $\mathrm{a}$ & 204 & 2 & 6 & 4 \\
\hline Oligochaeta & 48 & $a b$ & 96 & $\mathrm{a}$ & 3 & $\mathrm{~b}$ & 42 & $a b$ & 169 & 249 & 90 & 109 \\
\hline Opiliones & 0 & $\mathrm{a}$ & 0 & $\mathrm{a}$ & 0 & $\mathrm{a}$ & 3 & $\mathrm{a}$ & 447 & - & - & - \\
\hline Orthoptera & - & & - & & - & & - & & & 1 & 29 & 6 \\
\hline Others $^{c}$ & - & & - & & - & & - & & & 60 & 16 & 10 \\
\hline $\mathrm{n}^{\mathrm{d}}$ & 5 & & 5 & & 5 & & 5 & & & 8 & 5 & 5 \\
\hline
\end{tabular}

${ }^{\mathrm{a} C o f f e e ~ t r e e s ~ i n t e r c r o p p e d ~ w i t h ~} S$. amazonicum or H. brasiliensis. ${ }^{\mathrm{b}}$ Numbers with the same letter in a row do not differ significantly $(p<0.1)$. ${ }^{\mathrm{C} O t h e r s: ~ S u m ~ o f ~ o r g a n i s m s ~ o f ~ g r o u p s ~ a p p e a r i n g ~ l e s s ~ f r e q u e n t l y . ~}{ }^{\mathrm{d}} \mathrm{n}=$ number of replicates.

Table 3. Soil fauna sampled with traps under coffee trees under conventional (CC), organic (OC) and integrated management systems intercropped with $A$. pintoi (IA) or B. decumbens (IB).

\begin{tabular}{|c|c|c|c|c|c|c|c|c|c|}
\hline \multirow{2}{*}{ Group } & \multicolumn{2}{|c|}{$\mathrm{CC}$} & \multicolumn{2}{|c|}{ OC } & \multicolumn{2}{|c|}{ IB } & \multicolumn{2}{|c|}{ IA } & \multirow{2}{*}{$\frac{C V}{(\%)}$} \\
\hline & & & ------- & ivid & per tr: & ----- & & & \\
\hline Acarina & 2.9 & $a b^{a}$ & 1.2 & $\mathrm{~b}$ & 3.1 & $a b$ & 6.1 & $\mathrm{a}$ & 117 \\
\hline Araneae & 2.0 & $\mathrm{a}$ & 1.3 & $a b$ & 0.9 & $\mathrm{~b}$ & 0.3 & b & 112 \\
\hline Blattodea & 0.1 & $\mathrm{~b}$ & 0.1 & $\mathrm{~b}$ & 0.9 & b & 0.3 & $a b$ & 211 \\
\hline Coleoptera & 0.4 & $a b$ & 0.2 & b & 0.4 & $a b$ & 0.9 & $\mathrm{a}$ & 136 \\
\hline Collembola & 25.3 & $\mathrm{a}$ & 6.2 & $\mathrm{~b}$ & 16.1 & $a b$ & 24.3 & $\mathrm{a}$ & 70 \\
\hline Diptera (larvae) & 26.3 & a & 13.4 & b & 12.7 & b & 26.7 & $\mathrm{a}$ & 54 \\
\hline Homoptera & 0.1 & $\mathrm{~b}$ & 0.2 & $\mathrm{~b}$ & 4.0 & $\mathrm{a}$ & 1.6 & $\mathrm{~b}$ & 161 \\
\hline Hymenoptera & 8.2 & $\mathrm{a}$ & 9.2 & $\mathrm{a}$ & 13.8 & $\mathrm{a}$ & 12.0 & a & 74 \\
\hline Isopoda & 3.2 & $\mathrm{~b}$ & 62.1 & a & 0.0 & $\mathrm{~b}$ & 0.0 & b & 150 \\
\hline Isoptera & 0.0 & $\mathrm{~b}$ & 0.0 & b & 0.7 & $\mathrm{a}$ & 0.0 & b & 300 \\
\hline Lepidoptera (larvae) & 0.2 & $\mathrm{a}$ & 0.2 & $\mathrm{a}$ & 0.2 & $\mathrm{a}$ & 0.3 & $\mathrm{a}$ & 182 \\
\hline Opiliones & 0.0 & $\mathrm{a}$ & 0.2 & a & 0.1 & $\mathrm{a}$ & 0.2 & a & 311 \\
\hline Orthoptera & 0.4 & $a b$ & 0.0 & $\mathrm{~b}$ & 1.0 & $\mathrm{a}$ & 0.4 & $\mathrm{ab}$ & 169 \\
\hline
\end{tabular}

${ }^{\mathrm{a} N u m b e r s}$ with the same letter in a row are not significantly different $(p \leq 0.1)$. 


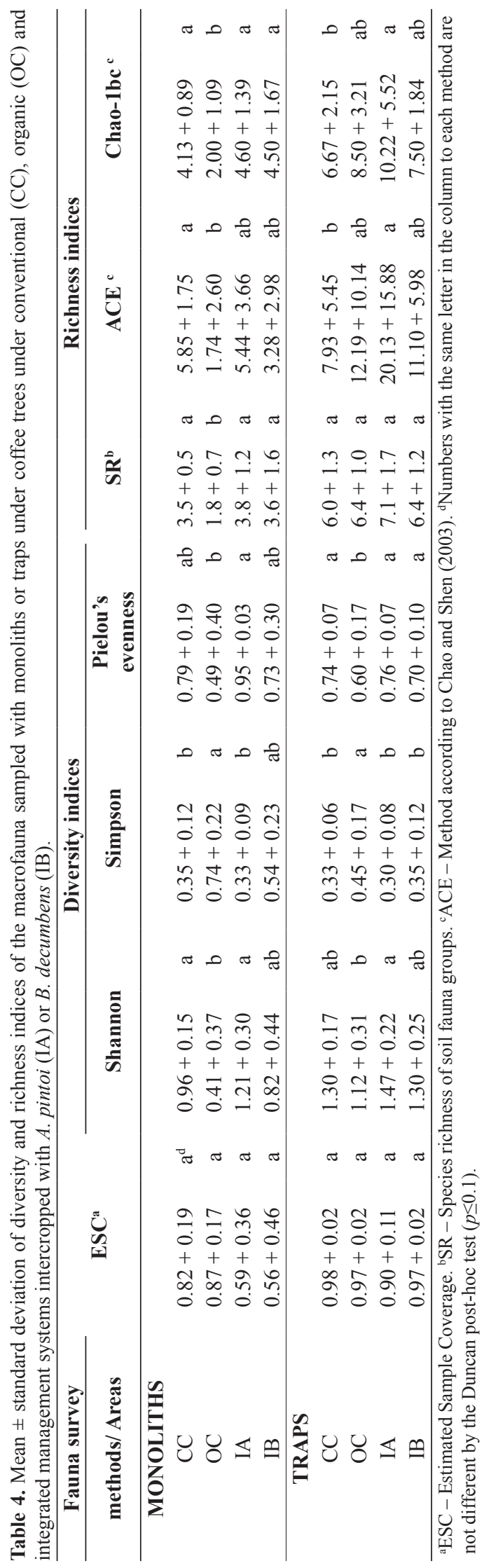


of Collembola in OC. The presence of Diptera was greater in $\mathrm{CC}$ and IB, while Homoptera were present in larger numbers in IA and IB. However, the most evident finding was the high density of Isopoda in OC (Table 3).

In general, soil monoliths data in OC had the lowest richness and diversity values, while IA had the highest diversity. The fauna sampled by traps was apparently more reliable to evaluate richness, diversity and equitability values in the different areas, since it presented lower standard deviation (Table 4).

\subsection{Canonical correlation analysis (CCA)}

The result of the CCA correlating edaphic fauna obtained with the trap method (response variable) and biological attributes (explanatory variables) was shown to be useful in distinguishing between management systems and to visualize the relationships among variables (Figure 1). In this analysis the separation of the soil management systems according to the TOC content became clear. The OC was characterized by a greater TOC and higher Isopoda values. The CC showed the greatest MBN values and a different faunal composition from the OC. The IA was positively correlated with greater $\mathrm{MBC}$ values and greater density of organisms belonging to Isoptera.

The evaluated enzymes did not show a good correlation with all the soil attributes data together, and, therefore, an independent analysis was performed (Figure 2). The OC was related with the enzymes urease, phosphatase and Isopoda and all the other samples and variables were not clearly discriminated.

The CCAs that were calculated with the data from the monolith method were unable to discriminate among the management systems studied and are not shown.

\section{Discussion}

\subsection{TOC, $\mathrm{C}-\mathrm{CO}_{2}, \mathrm{MBC}$ and $\mathrm{MBN}$}

The main difference among the studied management systems is the TOC content. The highest TOC level was found in $\mathrm{OC}$, and this certainly is a consequence of the greater addition of organic materials, grain husks and castor bean cake, which have a $\mathrm{C} / \mathrm{N}$ ratio around $31 / 1$ and $10 / 1$, respectively (Conceição et al., 2005; Monaco et al., 2008). There was addition of organic matter in the CC as well, but only in the form of a much smaller amount of coffee husk, while in the IA and IB there was the addition of leaf residues from $A$. pinto $i$ and $B$. decumbens plants with a $\mathrm{C} / \mathrm{N}$ ratio of about $30 / 1$ and $60 / 1$ respectively.

Comparing the two cover crops, the greater TOC level in the IB than IA is most probably related to a greater primary production and a greater $\mathrm{C} / \mathrm{N}$ ratio of the residues produced, thus promoting the buildup of carbon in the soil when grasses are used as cover. Legumes, on the other hand, experience a faster decomposition and a smaller accumulation in the soil (Oliveira et al., 2008; Thomas and Asakawa, 1993). In this study, $\mathrm{N}$ from $A$. pinto $i$ was not quantified, but legume crop residues, depending on type and quality, usually contain from $80-150 \mathrm{~kg} \mathrm{ha}^{-1}$ of
$\mathrm{N}$ (Shah et al., 2003), which favors the mineralization of organic residues and consequently results in a smaller accumulation of carbon in the soil.

The addition of residues with a low $\mathrm{C} / \mathrm{N}$ ratio tends to stimulate microbial biomass growth, as observed for $\mathrm{MBC}$ in the IA and OC. Moreover, organic management usually shows higher level of MBC when compared to conventional management system (Ge et al., 2011, 2013; Lagomarsino et al., 2009; Mäder et al., 2002). The MBC could be used as an indicator for the most sustainable management system on coffee production. This is strengthened by the fact that among some biological soil attributes, Partelli et al. (2012) found the MBC as the variable with higher relative contribution to the discrimination between conventional and organic production system of Coffea canephora.

Different effects have, however, been observed depending on the type of residue added to the soil. As for $\mathrm{MBN}$, the highest value was observed in IA and that may be due to the immobilization of nitrogen in the microbial biomass as a result of the addition of coffee husk with a high $\mathrm{C} / \mathrm{N}$ ratio $(31 / 1)$.

The basal respiratory rate, as well as the specific biomass respiration, $q \mathrm{CO}_{2}$, is also influenced by the quality of the residue added to the soil. Thus, residues with a greater $\mathrm{C} / \mathrm{N}$ ratio cause a higher respiration rate during the decomposition of these residues (Nogueira et al., 2006), as observed in CC and IB.

\subsection{Enzymatic activity}

Soil enzymes are influenced by a number of natural and anthropogenic factors which considerably modify their properties and performance (Chaer et al., 2009; Rao et al., 2014). Practices which favor microbial activity, such as organic fertilization, crop rotation, conservationist management and between-row cover also favor a greater enzymatic activity (Balota and Chaves, 2010; Bowles et al., 2014; Gajda and Martyniuk, 2005).

In general terms, a greater enzymatic activity was found in the organic management area (Table 1, Figure 2). The use of organic residues as coffee husk and castor bean cake for fertilization stimulated the activity of enzymes which act on the decomposition of organic residues, such as, arylsulphatase, urease and phosphatase (Liang et al., 2014; Tu et al., 2006). Dehydrogenase activity is related to microbial activity in general and is stimulated by the addition or prevalence of organic matter in the soil (Liang et al., 2014; Nogueira et al., 2006). In fact, the higher values were associated with higher TOC, and the lowest value was detected in IA that also presented the lowest TOC.

\subsection{Mycorrhizal colonization and AMF spore density in the soil}

AMF colonization depends on factors such as the AMF species present, the edapho-climatic conditions, the plant cultivar and the land management in use (Andrade et al., 2009). However, most of the studies reporting colonization on coffee were done in inoculation treatments or under greenhouse 
conditions (Andrade et al., 2010; Vaast et al., 1997; Siqueira et al., 1998), and there is scarcity of data on field evaluations. From this study, the colonization level of AMF ranged from 18 to $31 \%$ in coffee trees growing in intercropped, conventional or organic management.

The low levels of mycorrhizal colonization (most treatment around $20 \%$ ) could be explained by a satisfactory $\mathrm{P}$ nutrition of the plants. Brachiaria is a good host for the multiplication of AMF, and this may explain why there was a higher percent colonization in coffee plantations intercropped with this grass, although no differences in spore numbers were shown.

Differences in crop management can influence the spore number and colonization levels (Bainard et al., 2011). Besides, depending on the host plant and AMF species, there could be different strategies for colonization and sporulation of AMF and, sometimes, a change in one of these factors could alter the colonization behavior of the AMF. Coffee plant shaded by leguminous trees stimulates the spore number in soil compared with non-leguminous ones (Muleta et al., 2007). Intercropping also could increase the colonization level and the benefits from the arbuscular mycorrhiza (Bainard et al., 2011).

However, our results indicate that most of the variables did not affect the mycorrhizal status in coffee plants; only the higher colonization level in coffee plantations integrated with Brachiaria sp. was clearly correlated. The dense root system of Brachiaria sp. increases the chances for association with AM fungi, thereby producing more diverse propagules in soil and enhancing the possibility to colonize the coffee tree roots (Bainard et al., 2011).

\subsection{Soil fauna}

Faunal community structure was more important to differentiate the management systems than diversity. While diversity and richness indexes were not good to separate the management systems, since the values were quite similar (Table 4), the community's structures were clearly different (Tables 2 and 3, Figure 1).

Analyzing the differences of faunal community structure by the monolith method, Oligochaeta, Coleoptera and Lepidoptera (larvae) showed most evident differences among the sampled systems, comparing with the trap technique. Oligochaeta presented higher occurrence in OC. It can be explained by the absence of pesticides and a greater amount of soil organic matter. In fact, a greater occurrence of Oligochaeta in more sustainable management systems, such as the OC, would be expected, since this group is considered a good indicator of soil quality (Baretta et al., 2007b; Bartz et al., 2013). Coleoptera abundance was lower in OC, and its faunal group can be influenced by shadow level, which may be an explanation for the higher abundance in IB areas, where shadow level was higher due the green manure presence (Henderson and Roitberg, 2006; Nestel et al., 1993).

When sampling was performed with the monolith technique, different authors observed great variations in the structures of the soil faunal communities (Table 2), restricting the possibility of identification of typical patterns (Barros et al., 2002; Velasquez et al., 2007). Thus, the use of monoliths in studies in which the macrofauna will be used as an indicator of soil quality under coffee trees may sometimes not be the best option. In spite of the low reproducibility and the difficulty in finding patterns, the monolith is one of the most frequently used methods to study soil fauna, because it looks at all kinds, not only the more mobile epigeous fauna (Baretta et al., 2007a, b; Barros et al., 2002; Bignell, 2009; Velasquez et al., 2007). But, since it is a technique that is laborious and highly variable, sampling a greater number of replicates becomes necessary and this constitutes a major limitation to this method (Baretta et al., 2007a).

The trap method, although limited to certain groups, is operationally easier; the data obtained had greater reproducibility and provided clearer patterns of the edaphic fauna. This methodology is more reliable in comparative studies, especially when considering organisms with greater mobility in the surface (Baretta et al., 2007a).

By analyzing the faunal structures with the trap method, the high density of Isopoda in the OC was the most evident aspect of the soil fauna evaluation, indicating areas with low pesticide use and with high organic matter content (Karanja et al., 2009; Paoletti, 1999). In the IA area a greater occurrence of Isoptera was correlated with a higher $\mathrm{MBC}$, which may be related to higher presence of fungus in these areas (Jouquet et al., 2005; Riggins et al., 2014). The reduced presence of Collembola and Coleoptera in the organic system was a surprise, since they are usually correlated with a high organic matter content and absence of pesticides. Another unexpected result was the larger populations of Araneae, Collembola and Diptera (larvae) in areas where pesticides were applied, since these groups are usually considered as sensitive indicators (Maluche-Baretta et al., 2006).

\subsection{Canonical correlation analysis (CCA)}

Although the CCA proved to be a good tool to visualize the community structure and the interactions of the soil fauna, it produced a more reliable graph, when only the data of the trap method were used (Figure 1). TOC was the soil attribute most influenced by the different management systems. TOC content was higher for the OC, and lower in IA, and also influenced the other soil attributes. Of all orders identified, Isopoda and Isoptera stand out. Isopoda was an indicator of OC, being associated with high TOC values, while Isoptera was an indicator of IA, being associated with high MBC values (Jouquet et al., 2005; Karanja et al., 2009; Paoletti, 1999). For the enzymes, it was possible to visualize a higher activity in the OC, and again the relationship between Isopoda and OC was detected (Figure 2).

Since the biological attributes were mainly driven by TOC, and in general were higher in OC, it is very likely that increasing the input of organic matter in the other 
management systems will result in a higher biological activity.

\section{Conclusions}

TOC content was the soil attribute most influenced by the different coffee management systems, being the greatest content found in OC and the lowest in IA. TOC also influenced the other attributes evaluated. Faunal structure was more sensitive to distinguish the management systems than the other biological parameters. Among the faunal organisms, Isopoda was the best indicator of OC, being associated with high TOC values, while Isoptera was the group linked to IA, being associated with high $\mathrm{MBC}$ values. The $\mathrm{CC}$ and IB were more similar to each other, and discrimination of all four systems was only possible when the attributes were individually analyzed.

Little is reported about these attributes and its relations to coffee plantations, and an increasing data base will be important to establish parameters of biological sustainability in soils.

The management systems had distinct values for the different attributes, however, OC had higher values for most of the biological attributes and higher number of Oligochaeta and Isopoda, important soil quality indicators, corroborating the concept that $\mathrm{OC}$ is a more sustainable system.

\section{Acknowledgements}

The authors wish to thank the technicians Denise Mescolotti and Fernando Baldesin and the students of the course LSO 805 for their help with the analyses; Fundação de Pesquisa do Estado de São Paulo (FAPESP) and Conselho Nacional de Desenvolvimento Científico e Tecnológico (CNPq) for the funding; and Mr. José Peres Romero and Fazenda Lambari for providing the study areas. EJBNC acknowledges a grant from CNPq.

\section{References}

ANDERSON, J.D. and DOMSCH, K.H., 1989. Ratio of microbial biomass carbon to total organic carbon in arable soils. Soil Biology \& Biochemistry, vol. 21, no. 4, pp. 471-479. http://dx.doi. org/10.1016/0038-0717(89)90117-X.

ANDERSON, T.H., 2003. Microbial eco-physiological indicators to assess soil quality. Agriculture, Ecosystems \& Environment, vol. 98 , no. 1-3, pp. 285-293. http://dx.doi.org/10.1016/S01678809(03)00088-4.

ANDRADE, S.A.L., MAZZAFERA, M.A., SCHIAVINATO, M.A. and SILVEIRA, A.P.D., 2009. Arbuscular mycorrhizal association in coffee. The Journal of Agricultural Science, vol. 147, no. 2, pp. 105-115. http://dx.doi.org/10.1017/S0021859608008344.

ANDRADE, S.A.L., SILVEIRA, A.P.D. and MAZZAFERA, M.A., 2010. Arbuscular mycorrhiza alters metal uptake and the physiological response of Coffea arabica seedlings to increasing $\mathrm{Zn}$ and $\mathrm{Cu}$ concentrations in soil. The Science of the Total Environment, vol. 408, no. 22, pp. 5381-5391. http://dx.doi. org/10.1016/j.scitotenv.2010.07.064. PMid:20716461.
BAINARD, L.D., KLIRONOMOS, J.N. and GORDON, A.M., 2011. Arbuscular mycorrhizal fungi in tree-based intercropping systems: a review of their abundance and diversity. Pedobiologia, vol. 54, no. 2, pp. 57-61. http://dx.doi.org/10.1016/j.pedobi.2010.11.001.

BALOTA, E.L. and CHAVES, J.C.D., 2010. Enzymatic activity and mineralization of carbon and nitrogen in soil cultivated with coffee and green manures. Revista Brasileira de Ciencia do Solo, vol. 34, no. 5, pp. 1573-1583. http://dx.doi.org/10.1590/S010006832010000500010 .

BARETTA, D., BRESCOVIT, A.D., KNYSAK, I. and CARDOSO, E.J.B.N., 2007a. Trap and soil monolith sampled edaphic spiders (Arachnida: Araneae) in Araucaria angustifolia forest. Scientia Agricola, vol. 64, no. 4, pp. 375-383. http://dx.doi.org/10.1590/ S0103-90162007000400008.

BARETTA, D., BROWN, G.G., JAMES, S.W. and CARDOSO, E.J.B.N., 2007b. Earthworm populations sampled using collection methods in Atlantic forests with Araucaria angustifolia. Scientia Agricola, vol. 64, no. 4, pp. 384-392. http://dx.doi.org/10.1590/ S0103-90162007000400009.

BARROS, E., PASHANASI, B., CONSTANTINO, R. and LAVELLE, P., 2002. Effects of land-use system on the soil macrofauna in western Brazilian Amazonia. Biology and Fertility of Soils, vol. 35, no. 5, pp. 338-347. http://dx.doi.org/10.1007/ s00374-002-0479-z.

BARTZ, M.L.C., PASINI, A. and BROWN, G.G., 2013. Earthworms as soil quality indicators in Brazilian no-tillage systems. Applied Soil Ecology, vol. 69, pp. 39-48. http://dx.doi.org/10.1016/j. apsoil.2013.01.011.

BHARDWAJ, A.K., JASROTIA, P., HAMILTON, S.K. and ROBERTSON, G.P., 2011. Ecological management of intensively cropped agro-ecosystems improves soil quality with sustained productivity. Agriculture, Ecosystems \& Environment, vol. 140, no. 3, pp. 419-429. http://dx.doi.org/10.1016/j.agee.2011.01.005.

BIGNELL, D.E., 2009. Towards a universal sampling protocol for soil biotas in the humid tropics. Pesquisa Agropecuaria Brasileira, vol. 44, no. 8, pp. 825-834. http://dx.doi.org/10.1590/ S0100-204X2009000800005.

BLANCO-CANQUI, H., SHAPIRO, C.A., WORTMANN, C.S., DRIJBER, R.A., MAMO, M., SHAVER, T.M. and FERGUSON, R.B., 2013. Soil organic carbon: the value to soil properties. Journal of Soil and Water Conservation, vol. 68, no. 5, pp. 129A-134A. http://dx.doi.org/10.2489/jswc.68.5.129A.

BOWLES, T.M., ACOSTA-MARTÍNEZ, V., CALDERÓN, F. and JACKSON, L.E., 2014. Soil enzyme activities, microbial communities, and carbon and nitrogen availability in organic agroecosystems across an intensively-managed agricultural landscape. Soil Biology \& Biochemistry, vol. 68, pp. 252-262. http://dx.doi.org/10.1016/j.soilbio.2013.10.004.

BRASIL. Companhia Nacional de Abastecimento - CONAB, 2014 [viewed 1 April 2014]. Monitoring of the brazilian coffee crop, 2014 cropping season, first survey, jan./2014 [online]. Brasília. In portuguese. Available from: http://www.conab.gov.br

BRUSSAARD, L., RUITER, P.C. and BROWN, G.G., 2007. Soil biodiversity for agricultural sustainability. Agriculture, Ecosystems \& Environment, vol. 121, no. 3, pp. 233-244. http:// dx.doi.org/10.1016/j.agee.2006.12.013.

CASIDA-JÚNIOR, L.E., KLEIN, D.A. and SANTORO, R., 1964. Soil dehydrogenase activity. Soil Science, vol. 98, no. 6, pp. 371-378. http://dx.doi.org/10.1097/00010694-196412000-00004. 
CHAER, G.M., MYROLD, D.D. and BOTTOMLEY, P.J., 2009. A soil quality index based on the equilibrium between soil organic matter and biochemical properties of undisturbed coniferous forest soils of the Pacific Northwest. Soil Biology \& Biochemistry, vol. 41, no. 4, pp. 822-830. http://dx.doi.org/10.1016/j.soilbio.2009.02.005.

CHAO, A. and SHEN, T.J., 2003 [viewed 17 August 2013]. Program SPADE (Species Prediction and Diversity Estimation) and user's guide [online]. Taiwan. Available from: http://chao. stat.nthu.edu.tw/software/SPADE/SPADE_UserGuide.pdf

COLEMAN, D.C., 2008. From peds to paradoxes: linkages between soil biota and their influences on ecological processes. Soil Biology \& Biochemistry, vol. 40, no. 2, pp. 271-289. http:// dx.doi.org/10.1016/j.soilbio.2007.08.005.

CONCEIÇÃO, P.C., AMADO, T.J.C. and MIELNICZUK, J., 2005. Soil organic matter and other attributes as indicators to evaluate soil quality in conservation systems. Revista Brasileira de Ciencia do Solo, vol. 29, pp. 777-788.

COTRUFO, M.F., WALLENSTEIN, M.D., BOOT, C.M., DENEF, K. and PAUL, E., 2013. The Microbial Efficiency-Matrix Stabilization (MEMS) framework integrates plant litter decomposition with soil organic matter stabilization: do labile plant inputs form stable soil organic matter? Global Change Biology, vol. 19, no. 4, pp. 988-995. http://dx.doi.org/10.1111/gcb.12113. PMid:23504877.

DORAN, J.W. and ZEISS, M.R., 2000. Soil health and sustainability: managing the biotic component of soil quality. Applied Soil Ecology, vol. 15, no. 1, pp. 3-11. http://dx.doi.org/10.1016/ S0929-1393(00)00067-6.

GAJDA, A. and MARTYNIUK, S., 2005. Microbial biomass $\mathrm{C}$ and $\mathrm{N}$ and activity of enzymes in soil under winter wheat grown in different crop management systems. Polish Journal of Environmental Studies, vol. 14, pp. 159-163.

GARRIGUES, E., CORSON, M.S., ANGERS, D.A., VAN DER WERF, H.M. and WALTER, C., 2012. Soil quality in Life Cycle Assessment: towards development of an indicator. Ecological Indicators, vol. 18, pp. 434-442. http://dx.doi.org/10.1016/j. ecolind.2011.12.014.

GE, T., CHEN, X., YUAN, H., LI, B., ZHU, H., PENG, P., LI, K., JONES, D.L. and WU, J., 2013. Microbial biomass, activity, and community structure in horticultural soils under conventional and organic management strategies. European Journal of Soil Biology, vol. 58, pp. 122-128. http://dx.doi.org/10.1016/j.ejsobi.2013.07.005.

GE, T., NIE, S., WU, J., SHEN, J., XIAO, H., TONG, C., HUANG, D., HONG, Y. and IWASAKI, K., 2011. Chemical properties, microbial biomass, and activity differ between soils of organic and conventional horticultural systems under greenhouse and open field management: a case study. Journal of Soils and Sediments, vol. 11, no. 1, pp. 25-36. http://dx.doi.org/10.1007/ s11368-010-0293-4.

GERDEMANN, J.W. and NICOLSON, T.H., 1963. Spores of mycorrhizal Endogone species extracted from soil by wet sieving and decanting. Transactions of the British Mycological Society, vol. 46, no. 2, pp. 235-244. http://dx.doi.org/10.1016/ S0007-1536(63)80079-0.

HENDERSON, A.E. and ROITBERG, B.D., 2006. Microhabitat location of Exophthalmus jekelianus (White)(Coleoptera: Curculionidae): Is there a preference for shade-grown coffee? Environmental Entomology, vol. 35, no. 6, pp. 1603-1609. http:// dx.doi.org/10.1093/ee/35.6.1603.
INTERNATIONAL COFFEE ORGANISATION - ICO, 2014 [viewed 1 April 2014]. Total production of exporting countries [online]. London. Available from: http://dev.ico.org/prices/po.htm

JOUQUET, P., RANJARD, L., LEPAGE, M. and LATA, J.C., 2005. Incidence of fungus-growing termites (Isoptera, Macrotermitinae) on the structure of soil microbial communities. Soil Biology \& Biochemistry, vol. 37, no. 10, pp. 1852-1859. http://dx.doi. org/10.1016/j.soilbio.2005.02.017.

KARANJA, N.K., AYUKE, F.O., MUYA, E.M., MUSOMBI, B.K. and NYAMASYO, G.H.N., 2009. Soil macrofauna community structure across land use systems of Taita, Kenya. Tropical and Subtropical Agroecosystems, vol. 11, pp. 385-396.

LAGOMARSINO, A., MOSCATELLI, M.C., DI TIZIO, A., MANCINELLI, R., GREGO, S. and MARINARI, S., 2009. Soil biochemical indicators as a tool to assess the short-term impact of agricultural management on changes in organic $\mathrm{C}$ in a Mediterranean environment. Ecological Indicators, vol. 9, no. 3, pp. 518-527. http://dx.doi.org/10.1016/j.ecolind.2008.07.003.

LEPS, J. and SMILAUER, P., 2003. Multivariate analysis of ecological data using CANOCO. Cambridge: Cambridge University Press. 284 p.

LIANG, Q., CHEN, H., GONG, Y., YANG, H., FAN, M. and KUZYAKOV, Y., 2014. Effects of 15 years of manure and mineral fertilizers on enzyme activities in particle-size fractions in a North China Plain soil. European Journal of Soil Biology, vol. 60, pp. 112-119. http://dx.doi.org/10.1016/j.ejsobi.2013.11.009.

LIMA, A.C.R., BRUSSAARD, L., TOTOLA, M.R., HOOGMOED, W.B. and GOEDE, R.G.M., 2013. A functional evaluation of three indicator sets for assessing soil quality. Applied Soil Ecology, vol. 64, pp. 194-200. http://dx.doi.org/10.1016/j.apsoil.2012.12.009.

MÄDER, P., FLIESSBACH, A., DUBOIS, D., GUNST, L., FRIED, P. and NIGGLI, U., 2002. Soil fertility and biodiversity in organic farming. Science, vol. 31, no. 5573, pp. 1694-1697. http://dx.doi.org/10.1126/science.1071148. PMid:12040197.

MALUCHE-BARETTA, C.R.D., AMARANTE, C.V.T. and KLAUBERG-FILHO, O., 2006. Análise multivariada de atributos do solo em sistemas convencional e orgânico de produção de maças. Pesquisa Agropecuaria Brasileira, vol. 41, no. 10, pp. 1531-1539. http://dx.doi.org/10.1590/S0100-204X2006001000011.

MONACO, S., HATCH, D.J., SACCO, D., BERTORA, C. and GRIGNANI, C., 2008. Changes in chemical and biochemical soil properties induced by 11 -yr repeated additions of different organic materials in maize-based forage systems. Soil Biology \& Biochemistry, vol. 40, no. 3, pp. 608-615. http://dx.doi. org/10.1016/j.soilbio.2007.09.015.

MULETA, D., ASSEFA, F., NEMOMISSA, S. and GRANHALL, U., 2007. Composition of coffee shade tree species and density of indigenous arbuscular mycorrhizal fungi (AMF) spores in Bonga natural coffee forest, southwestern Ethiopia. Forest Ecology and Management, vol. 241, no. 1-3, pp. 145-154. http://dx.doi. $\operatorname{org} / 10.1016 /$ j.foreco.2007.01.021.

NESTEL, D., DICKSCHEN, F. and ALTIERI, M., 1993. Diversity patterns of soil macro-Coleoptera in Mexican shaded and unshaded coffee agroecosystems: an indication of habitat perturbation. Biodiversity and Conservation, vol. 2, no. 1, pp. 70-78. http:// dx.doi.org/10.1007/BF00055104.

NOGUEIRA, M.A., ALBINO, U.B., BRANDÃO-JUNIOR, O., BRAUN, G., CRUZ, M.F., DIAS, B.A., DUARTE, R.T.D., GIOPPO, N.M.R., MENNA, P., ORLANDI, J.M., RAIMAM, M.P., 
RAMPAZO, L.G.L., SANTOS, M.A., SILVA, M.E.Z., VIEIRA, F.P., TOREZAN, J.M.D., HUNGRIA, M. and ANDRADE, G., 2006. Promising indicators for assessment of agroecosystems alteration among natural, reforested and agricultural land use in southern Brazil. Agriculture, Ecosystems \& Environment, vol. 115, no. 1-4, pp. 237-247. http://dx.doi.org/10.1016/j.agee.2006.01.008.

OLIVEIRA, F.F., GUERRA, J.G.M., ALMEIDA, D.L., RIBEIRO, R.L.D., ESPINDOLA, J.A.A., RICCI, M.S.F. and CEDDIA, M.B., 2008. Avaliação de coberturas mortas em cultura de alface sob manejo orgânico. Horticultura Brasileira, vol. 26, no. 2, pp. 216-220. http://dx.doi.org/10.1590/S0102-05362008000200017.

PAOLETTI, M.G., 1999. Using bioindicators based on biodiversity to assess landscape sustainability. Agriculture, Ecosystems \& Environment, vol. 74, no. 1-3, pp. 1-18. http://dx.doi.org/10.1016/ S0167-8809(99)00027-4.

PARTELLI, F.L., VIEIRA, H.D., FERREIRA, E.P.B., VIANA, A.P., MARTINS, M.A. and URQUIAGA, S., 2012. Chemical and microbiological soil characteristics under conventional and organic coffee production systems. Communications in Soil Science and Plant Analysis, vol. 43, no. 5, pp. 847-864. http://dx.doi.org/10. 1080/00103624.2012.648470.

RAO, M.A., SCELZA, R., ACEVEDO, F., DIEZ, M.C. and GIANFREDA, L., 2014. Enzymes as useful tools for environmental purposes. Chemosphere, vol. 107, pp. 145-162. http://dx.doi. org/10.1016/j.chemosphere.2013.12.059. PMid:24411841.

RIGGINS, J.J., LITTLE, N.S. and ECKHARDT, L.G., 2014. Correlation between infection by ophiostomatoid fungi and the presence of subterranean termites in loblolly pine (Pinus taeda L.) roots. Agricultural and Forest Entomology, vol. 16, no. 3, pp. 260-264. http://dx.doi.org/10.1111/afe.12053.

RUTGERS, M., VAN WIJNEN, H.J., SCHOUTEN, A.J., MULDER, C., KUITEN, A.M.P., BRUSSAARD, L. and BREURE, A.M., 2012. A method to assess ecosystem services developed from soil attributes with stakeholders and data of four arable farms. The Science of the Total Environment, vol. 415, pp. 39-48. http:// dx.doi.org/10.1016/j.scitotenv.2011.04.041. PMid:21704358.

SCHMIDT, M.W., TORN, M.S., ABIVEN, S., DITTMAR, T., GUGGENBERGER, G., JANSSENS, I.A., KLEBER, M., KÖGEL-KNABNER, I., LEHMANN, J., MANNING, D.A.C., NANNIPIERI, P., RASSE, D.P., WEINER, S. and TRUMBORE, S.E., 2011. Persistence of soil organic matter as an ecosystem property. Nature, vol. 478, no. 7367, pp. 49-56. http://dx.doi. org/10.1038/nature10386. PMid:21979045.

SHAH, Z., SHAH, S.H., PEOPLES, M.B., SCHWENKE, G.D. and HERRIDGE, D.F., 2003. Crop residue and fertilizer N effects on nitrogen fixation and yields of legume-cereal rotations and soil organic fertility. Field Crops Research, vol. 83, no. 1, pp. 1-11. http://dx.doi.org/10.1016/S0378-4290(03)00005-4.
SIQUEIRA, J.O., SAGGIN-JÚNIOR, O.J., FLORES-AYLAS, W.W. and GUIMARÃES, P.T.G., 1998. Arbuscular mycorrhizal inoculation and superphosphate application influences plant development and yield of coffee in Brazil. Mycorrhiza, vol. 7, no. 6, pp. 293-300. http://dx.doi.org/10.1007/s005720050195.

SOCARRÁS, A., 2013. Soil mesofauna: biological indicator of soil quality. Pastos y Forrajes, vol. 36, no. 1, pp. 14-21.

TABATABAI, M.A. and BREMNER, J.M., 1969. Use of pnitrophenyl-phosphate for assay of soil phosphatase activity. Soil Biology \& Biochemistry, vol. 1, no. 4, pp. 301-307. http:// dx.doi.org/10.1016/0038-0717(69)90012-1.

TABATABAI, M.A. and BREMNER, J.M., 1970. Arylsulphatase activity of soils. Soil Science Society of America Journal, vol. 34, no. 2, pp. 225-229. http://dx.doi.org/10.2136/sssaj1970.036 15995003400020016x.

TABATABAI, M.A. and BREMNER, J.M., 1972. Assay of urease activity in soil. Soil Biology \& Biochemistry, vol. 4, no. 4, pp. 479-487. http://dx.doi.org/10.1016/0038-0717(72)90064-8.

THOMAS, R.J. and ASAKAWA, N.M., 1993. Decomposition of leaf litter from tropical forage grasses and legumes. Soil Biology \& Biochemistry, vol. 25, no. 10, pp. 1351-1361. http://dx.doi. org/10.1016/0038-0717(93)90050-L.

TU, C., RISTAINO, J.B. and HU, S., 2006. Soil microbial biomass and activity in organic tomato farming systems: Effects of organic inputs and straw mulching. Soil Biology \& Biochemistry, vol. 38, no. 2, pp. 247-255. http://dx.doi.org/10.1016/j.soilbio.2005.05.002.

VAAST, P., CASWELL-CHEN, E.P. and ZASOSKI, R.J., 1997. Influences of a root-lesion nematode, Pratylenchus coffeae, and two arbuscular mycorrhizal fungi, Acaulospora mellea and Glomus clarum on coffee (Coffea arabica L.). Biology and Fertility of Soils, vol. 26, no. 2, pp. 130-135. http://dx.doi.org/10.1007/ s003740050355.

VAN RAIJ, B., ANDRADE, J.C., CANTARELLA, H. and QUAGGIO, J.A., 2001. Chemical analysis for evaluation of fertility in tropical soils. 3rd ed. Campinas: Instituto Agronômico de Campinas. 284 p. In portuguese.

VANCE, E.D., BROOKES, P.C. and JENKINSON, D.S., 1987. An extraction method for measuring soil microbial biomass C. Soil Biology \& Biochemistry, vol. 19, no. 6, pp. 703-707. http:// dx.doi.org/10.1016/0038-0717(87)90052-6.

VELASQUEZ, E., LAVELLE, P. and ANDRADE, M., 2007. GISQ, a multifuncional indicator of soil quality. Soil Biology \& Biochemistry, vol. 39, no. 12, pp. 3066-3080. http://dx.doi. org/10.1016/j.soilbio.2007.06.013.

VIERHEILIG, H., COUGHLAN, A.P., WYSS, U. and PICHÉ, Y., 1998. Ink and vinegar, a simple staining technique for arbuscularmycorrhizal fungi. Applied and Environmental Microbiology, vol. 64, no. 12, pp. 5004-5007. PMid:9835596. 